\title{
Gene Expression Evaluation of Multigenic Cotton (Gossypium hirsutum) against Cotton Leaf Curl Virus
}

\author{
Muhammad Rizwan Afzal ${ }^{1}$, Muhammad Tariq Manzoor ${ }^{1}$, Sajid Ali $^{1 *}$, Ammara Fatima ${ }^{2}$, Sadia Nawaz ${ }^{3}$, Muhammad \\ Rizwan Tariq ${ }^{1}$, Moazzam Anees ${ }^{1}$, Muhammad Atif ${ }^{1}$, Nida Rafaqat ${ }^{1}$ and Ahmad Ali Shahid ${ }^{4}$ \\ ${ }^{1}$ Faculty of Agricultural Sciecnces/University of the Punjab, Lahore-54590, Pakistan \\ ${ }^{2}$ Department of Environmental Science, Lahore College for Women University, Lahore, Pakistan \\ ${ }^{3}$ Institute of Biochemistry and Biotechnology, University of Veterinary and Animal Sciences, Lahore, Pakistan \\ ${ }^{4}$ Centre of excellence and molecular biology/ University of the Punjab, Lahore-54590, Pakistan \\ *For correspondence: sajid.agronomy@ pu.edu.pk \\ Received 07 January 2021; Accepted 23 April 2021; Published 10 June 2021
}

\begin{abstract}
One of the most crucial threats limiting the sustainable production of cotton is cotton leaf curl disease (CLCuD). There is dire need to produce a resistant variety that can combat CLCuD. For this purpose, virus resistant transgenic cotton plants (MNH786) with $\mathrm{C} 4$ gene construct at T3 generation were selected and sown. Young fresh leaves of multigenic variety of MNH-786 were collected to confirm the transformed construct. Infected whiteflies were used for spreading on transgenic cotton MNH786 variety with $\mathrm{C} 4$ construct to check percentage of infection. Whiteflies were collected from infected cotton plants showing $\mathrm{CLCuD}$ and reared in lab to increase the population of whiteflies. After 15 days of feeding, infected leaves of transgenic plants were collected and total DNA of infected leaves of transgenic cotton plant with virus load was extracted. At maturity, data of morphological characteristic was taken from the transgenic cotton plants of MNH-786 and control plants. Resistant transgenic cotton plants showed $<0.5 \%$ disease index and recorded more plant height in field condition. Total number of bolls per plant was $20 \%$ more in tolerant plants and $40 \%$ more in resistant plants as compared to susceptible plants. Molecular analysis of transgenic plants showed clear evidence that expression of construct 4 virus resistant gene against begomoviruses in resistant and tolerant group of transgenic plants was more as compared to susceptible group and control. (C) 2021 Friends Science Publishers
\end{abstract}

Keywords: Begomovirus; Whitefly; Clone; Resistance; Plasmid

\section{Introduction}

Cotton (Gossypium hirsutum L.) is one of major cash crops of Pakistan and contributes a strengthening role in Pakistan economy and in earning of foreign exchange. Cotton is the crop having global significance with respect to fibre and livestock feed (Rojo-Gutiérrez et al. 2020). Cotton is a raw material for the textile industry that contributes lot in economy of Pakistan. Along with textile uses, cotton seed oil is produced from cotton seed which is a rich source of oil and cotton seed cakes are also used as livestock feed. In Pakistan, cotton is the second most cultivated crop after wheat (Triticum aestivum). Gossypium genus contains almost 50 species from which $90 \%$ are diploid (2X) while rest are allotetraploid (4X) species (Ulloa and Messmer 2006). From these only four species are cultivated i.e., G. arboreaum L., G. herbaceum L., G. barbadense L. and most widely grown species $\mathrm{G}$. hirsutum L. with tetraploid genome. G. hirsutum L. has been known as the highest yielding and is cultivated more than $90 \%$ worldwide (An et al. 2007).
Commercial cultivated cotton crops are more susceptible to the insects and pathogens. Almost more than 30 species of fungi and, some bacteria and insects are involved in causing yield loss to cotton crop. Despite the continual improvement in the performance of control strategies, losses remain very high and certainly are not declining. The harvest losses are 30\% (animal pests $12 \%$, viruses $10 \%$ and weeds $7 \%$ ) (Oerke and Dehne 2004). In 1912, cotton leaf curl virus was found in Nigeria. Almost fifty years later, CLcuD was first recorded during 1967 in Multan (Pakistan) on scattered hirsutum plants and in Ghotki (Sindh) in 1996. At that time attention was not paid on this virus but later on in 1990s, this viral disease caused serious threats to crop in Pakistan. In Punjab during 1992-1993, CLcuD appeared as epidemic and cost a huge loss. About 97,580 hectares area was under severe attack of virus, which caused a loss 543,294 bales over one year. The financial losses with the estimated value of $\$ 5$ billion (US) to the nation occurred from 1992-1997 (Mansoor et al. 2001). 
In the very beginning, to overcome stresses many conventional ways were being adopted like early detection, seed treatments, crop rotations, avoiding cultivation of alternative host, breeding for resistance, chemical control of vectors and cross protection (Johnson 2000; Hull 2001). Plant resistance cannot be introduced efficiently thorough conventional breeding procedure. Later with the advance's biotechnology and molecular biology, conventional methods were reduced. Modern genomics and proteomics studies helped to produce improved yield crop varieties with disease resistance (Mittler and Blumwald 2010; Hernández-Centeno et al. 2020). With the passage of time, many techniques were developed that allow introduction of natural resistance gene in susceptible plants (Liu et al. 2002) and many plant resistance genes have been cloned (Rufell et al. 2002; Zhang and Gassmann 2003). Many different strategies have been documented to combat against different plant viruses. In plants that lack natural resistance, many genes have been incorporated to engineer pathogen derived resistance (sequence-derived from the pathogen itself) by RNA mediated technology (Ilyas et al. 2011). For Geminiviruses, numerous protein mediated resistance (coat protein mediated and movement protein mediated) approaches to achieving resistance in plant have been also investigated (Gallitelli and Accotto 2001). Resistance due to expression of the non-pathogen derived antiviral agents i.e., virus induced cell death and DNA binding protein from heterologous sources also introduced in cotton plants (Rojo-Gutiérrez et al. 2020). The wild Gossypium species namely $G$. thurberii, G. anomalum, $G$. raimondii, G. armourianum, and G. tomentosum are a good source of resistance to insect pests, such as boll-worms, jassids, whitefly and mites, and for resistance to diseases including bacterial blight, and verticillium wilt (Azhar et al. 2010).

Keeping in view the above discussion, this study was designed to investigate the tolerance of MNH-786 against the virus causing huge yield losses to white gold of Pakistan. A lot of work has already been done to cope with CuCLD and many varieties of cotton have been studied against it. Yet the threat to cotton by this fatal virus/disease has not been fully controlled. This study was conducted to confirm positive putative transgenic plants of this MNH-786 cotton variety at T3 Generation and to check variation in expression for virus resistant genes. Research objectives whether MNH-786 is resistant to CuCLD were accomplished by using various molecular techniques, white fly assay and the performance of the variety under field conditions.

\section{Materials and Methods}

Seeds of forty-five virus resistant transgenic cotton plants (MNH-786 cotton variety collected from CEMB) with C4 gene construct at $\mathrm{T} 3$ generation and five control cotton plants were sown in 50 clay pots and placed in green house located in CEMB (Center for Excellence in Molecular Biology). After germination, seedlings of these plants were transplanted in a plot on 10 rows, five plants each with 25 $\mathrm{cm}$ plant to plant and $75 \mathrm{~cm}$ row to row distance in high tunnel. All plants were used to confirm the transgene. The experiment was laid out in completely randomized design with 5 replications with 10 plants per replicate and 49 degrees of freedom (total).

\section{Confirmation of genetic transformed construct}

Young fresh leaves of multigenic variety of MNH-786 cotton variety from all the plots of high tunnel were collected to confirm the transformed construct. Genomic DNA of transgenic cotton plant with virus gene was extracted by CTAB method with some modification (Saha et al. 2002). To check the concentration and quantity of extracted DNA, it was run on $0.8 \%$ gel. To confirm the targeted Construct in transgenic plant genome, polymerase chain reaction was performed in Plant Lab of CEMB. For the amplification of 499 bp ( $\approx 500$ bp) fragment (Fig. 2), a reaction mixture was prepared by following ingredients: 5 $\mu \mathrm{L}$ of DNA as template, $2 \mu \mathrm{L}$ of $1 \mathrm{~m} M$ dNTPs, $2.5 \mu \mathrm{L}$ of 10 $\mathrm{X}$ Taq Buffer (Fermantas), $2.5 \mu \mathrm{L}$ of $\mathrm{MgCl}_{2}$ (Fermantas), 2 $\mu \mathrm{L}$ of $10 \mathrm{pmol}$ reverse primer pdk 5, ATTGACCTGGAACT 3', $2 \mu \mathrm{L}$ of 10 pmol forward primer pdk 5' ATGTGCACTAAGGCT 3', and $1 \mu \mathrm{L}$ Taq Polymerase enzyme (Fermantas). Final volume was adjusted to $20 \mu \mathrm{L}$ by adding injection water of $2 \mu \mathrm{L}$ in each reaction. These thermocycler conditions were given to PCR machine, initial denaturation was done at $95^{\circ} \mathrm{C}$ for 5 mins followed by 35 cycles of denaturation at $95^{\circ} \mathrm{C}$ for $1 \mathrm{~min}$. Annealing was carried out at $57^{\circ} \mathrm{C}$ for 1 min followed by extension at $72^{\circ} \mathrm{C}$ for $1 \mathrm{~min}$. Final extension was done at $72^{\circ} \mathrm{C}$ for $10 \mathrm{~min}$.

\section{Whitefly assay and RT-PCR}

Infected whiteflies were used for spreading on transgenic cotton $\mathrm{MNH}-786$ variety with $\mathrm{C} 4$ construct in order to check percentage of infection in cages under greenhouse condition (Fig. 1A, B) and to perform Real Time PCR for the quantification of Virus Titer.

\section{Rearing and collection of viruliferous whiteflies}

Whiteflies were collected from infected cotton plants showing $\mathrm{CLCuD}$ and reared in lab for two weeks at temperature of $28^{\circ} \mathrm{C}, 30-50 \%$ relative humidity, and $14-\mathrm{h}$ photoperiod for increase its population of whiteflies. Virus infested whiteflies were collected from the cage in Vial collector with the help of aspirator device with very gentle breath. Firstly, cage was little shaken to disperse the whiteflies and 20 whiteflies for each vial collector were collected by aspirator. These infested whiteflies were then taken to experimental area for transmission in green house. 


\section{Feeding of whiteflies on experimental plants}

On the basis of morphological symptoms, positive putative transgenic plants of MNH-786 variety were categorized in three categories i.e., resistant, tolerant and susceptible. These plants were placed in small cages little higher than plants. About 4 to 5 whiteflies were fed upon each leave and cages were locked carefully so they cannot escape. Temperature and humidity were also maintained in green house. Symptoms were noted on regular basis to check resistance level.

Total DNA of infected leaves of transgenic plants was extracted to check virus titter

After 15 days of feeding, infected leaves of transgenic plants were collected and total DNA of infected leaves transgenic cotton plant with virus load was extracted by CTAB method with some modification (Saha et al. 2002).

\section{Confirmation of presence of virus titter in total genomic DNA}

To confirm the viral load in genomic DNA of infected leaves, PCR was conducted. $\beta$-primers were designed to amplify the virus gene of $\mathrm{CLCuV}$ in the genome of infected leaves. To conduct PCR for this purpose, a reaction mixture was prepared by following ingredients: $4 \mu \mathrm{L}$ of DNA as template, $2 \mu \mathrm{L}$ of $1 \mathrm{~m} M$ dNTPs, $2 \mu \mathrm{L}$ of $10 \mathrm{X}$ Taq Buffer (Fermantas), $2 \mu \mathrm{L}$ of $\mathrm{MgCl}_{2}$ (Fermantas), $2 \mu \mathrm{L}$ of $10 \mathrm{pmol} \beta$ reverse primer pdk ATTAAAACGTGAAAAAGGTGAT 3', $2 \mu \mathrm{L}$ of $10 \mathrm{pmol}$ $\beta$ forward primer pdk 5' AGTGCGCTGAAAAAGGTGAT 3 , and $1 \mu \mathrm{L}$ Taq Polymerase enzyme (Fermantas). Final volume was adjusted to $20 \mu \mathrm{L}$ by adding injection water of $5 \mathrm{ul}$ in each reaction. The following thermocycler condition was given to PCR machine; initial denaturation at $95^{\circ} \mathrm{C}$ for 5 mins followed by 40 cycles of denaturation at $95^{\circ} \mathrm{C}$ for 45 $\mathrm{s}$, annealing at $54^{\circ} \mathrm{C}$ for $30 \mathrm{~s}$ followed by extension at $72^{\circ} \mathrm{C}$ for $45 \mathrm{~s}$. Final extension was done at $72^{\circ} \mathrm{C}$ for $7 \mathrm{~min}$.

\section{Quantification of virus titter through RT-PCR}

In order to quantify the concentration of virus load, a mentioned protocol in Maxima ${ }^{\circledR}$ SYBER Green/ROX for real time PCR was used. Real time PCR was conducted in an iQ5 cycler (BIO-RAD) with a 96-well plate. Reaction master mix was prepared by adding the following components except template DNA for each $15 \mu \mathrm{L}$ reaction to a micro centrifugation tube at room temperature: $7 \mu \mathrm{L}$ of Maxima ${ }^{\circledR}$ SYBR Green/ROX qPCR Master Mix (2x), 0.8 $\mu M$ of forward $\beta$ primers L1 5, AGTGCGCTGAAAAAGGTGAT ' $3,0.8 \mu M$ of reverse $\beta$ primers R1 5' ATTAAAACGTGAAAAAGGTGAT ' 3 , and to make volume water up to $15 \mu \mathrm{L}$ nuclease free water was added. Glyceraldehyde 3-phosphate dehydrogenase
(GAPDH) was used as internal control to normalize the data. The master mix was mixed thoroughly and appropriate volumes were dispensed into PCR plate. One ul of template DNA was added to individual wells containing the master mix. 96 well plates were centrifuged for short time to mix reaction components properly. To remove bubbles, mixed the gently otherwise bubbles interfered with the florescence detection. The reaction conditions were as follows, initial denaturation at $95^{\circ} \mathrm{C}$ for $5 \mathrm{~min}$ followed by 40 cycles of denaturation at $95^{\circ} \mathrm{C}$ for $45 \mathrm{~s}$, annealing at $54^{\circ} \mathrm{C}$ for $30 \mathrm{sec}$ followed by extension at $72^{\circ} \mathrm{C}$ for $45 \mathrm{~s}$. Final extension was done at $72^{\circ} \mathrm{C}$ for $7 \mathrm{~min}$.

\section{Field evaluation}

Plants were categorized on the basis of disease rating scale of $0-2$, where the plants with 0 disease rating $(1-5 \%$ disease index) were categorized as resistant, plants with 1 disease rating (-25\% disease index as tolerant and 2 disease rating $(\geq 25 \%$ disease index) as susceptible (Table 1).

At maturity, data of morphological characteristic was taken from seventy-five transgenic cotton plants of $\mathrm{MNH}$ 786 and five control plants from tunnel. Morphological characteristic like monopodial branches per plant, sympodial branches per plant, number of total leaves per plant, number of infected leaves per plant, number of bolls per plant, yield per plant and height of each plant were observed.

\section{Statistical analysis}

All the collected data were subjected to statistical analysis by using Statistix ${ }^{\circledR}$ version 8.9 statistical package. The significance of treatment means was tested by using Analysis of Variance (ANOVA) @ 5\% probability. Means were separated by using Least Significant Difference (LSD) test at $\alpha: 0.05$. Correlation and regression lines were carried out between percentage infection and other quantitative parameters as monopodial branches and percentage infection per plant, sympodial branches and percentage infection per plant, no of total leaves and percentage infection per plant, number of infected leaves and percentage infection per plant, number of bolls and percentage infection per plant, yield and percentage infection per plant and height and percentage infection per plant.

\section{Results}

Total number of leaves per plant and number of monopodial branches per plants showed non-significant differences among different groups of transgenic cotton variety used during the course of the study. Maximum sympodial branches per plant $(27.2 \pm 2.51)$ were studied in case of the control plants which were statistically at par with those of resistant plants $(25.0 \pm 7.52)$. Tolerant group of plants 
Table 1: Disease rating scale for transgenic cotton plants on basis of CLCuV symptoms

\begin{tabular}{|c|c|c|c|}
\hline SYMPTOMS & Disease rating & Disease index $(\%)$ & Plant category \\
\hline Small Scattered vein thickening on plants & 0 & $1-5$ & Resistant \\
\hline Large group of Vein thickening and leaf curling on plants & 1 & $5-25$ & Tolerant \\
\hline Sever vein thickening, leaf curling, leaf enation stunted growth of plants and less fruit production & 2 & $\geq 25$ & Susceptible \\
\hline
\end{tabular}

Table 2: Comparison of the morphological characteristics of tansgenic plant

\begin{tabular}{|c|c|c|c|c|c|c|c|c|}
\hline $\begin{array}{l}\text { Plant/Mor. } \\
\text { Char. }\end{array}$ & $\begin{array}{l}\text { Number of } \\
\text { plant }^{-1}\end{array}$ & monopoida & $\begin{array}{l}\text { Number of sympodia } \\
\text { plant }^{-1}\end{array}$ & $\begin{array}{l}\text { Total } \\
\text { plant }^{-1}\end{array}$ & $\begin{array}{l}\text { leaves Infected lea } \\
\text { plant }^{-1}\end{array}$ & s Bolls per plant & Yield $\left(\mathrm{g}\right.$ plant $\left.{ }^{-1}\right)$ & $\begin{array}{l}\text { Plant } \\
(\mathrm{cm})\end{array}$ \\
\hline Resistant & $3.2 \pm 1.10$ & & $25.0 \mathbf{a b} \pm 7.52$ & $99.6 \pm 30.48$ & $3.2 \mathbf{d} \pm 0.84$ & $29.6 \mathbf{a} \pm 5.22$ & $118.4 \mathbf{a} \pm 20.90$ & $38.6 \mathbf{a} \pm 3.36$ \\
\hline Tolerant & $2.0 \pm 1.58$ & & $18.2 \mathbf{c} \pm 3.96$ & $73.8 \pm 14.62$ & $16.0 \mathbf{c} \pm 4.30$ & $20.6 \mathbf{b} \pm 5.94$ & $82.4 \mathbf{b} \pm 23.77$ & $33.8 \mathbf{a} \pm 6.69$ \\
\hline Susceptible & $3.0 \pm 0.71$ & & $19.8 \mathbf{b c} \pm 3.19$ & $59.4 \pm 16.65$ & $29.6 \mathbf{b} \pm 6.19$ & $17.0 \mathbf{b} \pm 3.67$ & $68.0 \mathbf{b} \pm 14.70$ & $29.0 \mathbf{a} \pm 3.77$ \\
\hline Control & $3.0 \pm 0.34$ & & $27.2 \mathbf{a} \pm 2.51$ & $39.0 \pm 11.21$ & $67.4 \mathbf{a} \pm 2.45$ & $8.8 \mathbf{c} \pm 0.51$ & $27.2 \mathbf{c} \pm 2.03$ & $21.0 \mathbf{b} \pm 2.35$ \\
\hline$P(0.05)$ & 0.325 & & 0.027 & 0.493 & $<0.000$ & $<0.000$ & $<0.000$ & 0.052 \\
\hline LSD (0.05) & NS & & 6.38 & NS & 9.30 & 6.26 & 25.04 & 7.65 \\
\hline
\end{tabular}

* The values showing different letters within the column differ significantly

Table 3: Correlation of Infection Percentage with different growth and yield parameters $(n=50)$

\begin{tabular}{ll}
\hline Parameter & Percent Infection \\
Monopodial Branches & $0.078^{\mathrm{ns}}$ \\
Sympodial Branches & $0.009^{\mathrm{ns}^{*}}$ \\
Total number of leaves & $-0.341^{*}$ \\
Infected leaves & $0.909^{* *}$ \\
Yield (g per plant) & $-0.746^{* *}$ \\
Plant height $(\mathrm{cm})$ & $-0.118^{\mathrm{ns}}$ \\
\hline
\end{tabular}

Here ns $=$ Non-significant; $*$ Significant at $0.05 ; * *=$ Significant at 0.01

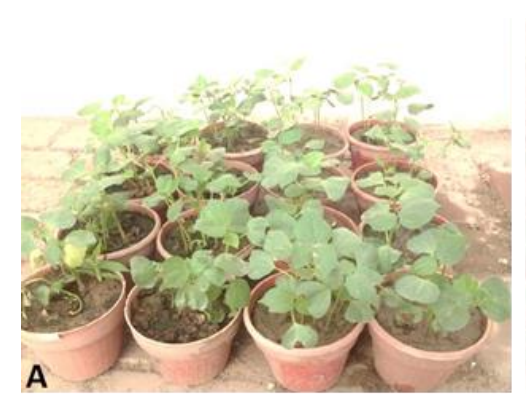

Fig. 1: A, B: Transgenic Plants of MNH-786 variety (C4-Construct)

showed minimum number of sympodial branches per plant $(18.2 \pm 3.96)$ which were statistically same with those of susceptible plants $(19.8 \pm 3.19)$. Resistant group of plants showed least number of infected leaves (3.2) which was statistically lowest and different from all other groups of the plants. Maximum leaves of the control plants (67.4) were infected by CuCLD which were significantly higher than that of all other groups of transgenic plants. Resistant group of plants showed maximum bolls per plant (29.6), yield (118.4 $\left.\mathrm{g} \mathrm{plant}^{-1}\right)$ and plant height $(38.6 \mathrm{~cm})$. Control group of plants resulted in minimum bolls per plant (8.8), yield $\left(27.2 \mathrm{~g} \mathrm{plant}^{-1}\right)$ and plant height $(21.0 \mathrm{~cm})($ Table 2$)$.

Total number of leaves (-0.341) and yield (-0.746) per plant were negatively correlated with disease infection while infected leaves per plant $(0.909)$ were positively correlated with disease infection percentage. However, number of monopodial and sympodial branches per plant and plant height had no association with disease infection percentage (Table 3).
The isolated DNA from transgenic cotton plants (MNH-786 Variety) elaborated in Fig. 3, which was further used to identify the presence of $\mathrm{C} 4$ construct using a specific gene primer. Genomic DNA of 45 transgenic plants had shown where, Lane 1 shows Lambda Hind III, Lane 2-14 show total DNA of transgenic plants (Fig. 3A), Lane 1-15 depicted total DNA of transgenic plants (Fig. 3B), and Lane 1-15 showed total DNA of transgenic plants (Fig. 3C).

A close observation of Fig. 4 demonstrated the PCR amplification of transgenic cotton with gene specific primers for $\mathrm{C} 4$ gene construct, and showed that out of total 45 transgenic plants, 35 plants showed presence of $\mathrm{C} 4$ gene construct whereas 10 plants did not show the $\mathrm{C} 4$ gene construct. Where, Lane 1 of the top lefut Feigure depicts 50 bp Ladder, Lane 2 exhibits amplified plasmid for positive control, Lane 3 explains the negative control, Lanes 4-7, 9-11 \& 13-15 showed positive transgenic plants and Lane 8 \& 12 depicted the non - transgenic plants (Fig. 4A). View 

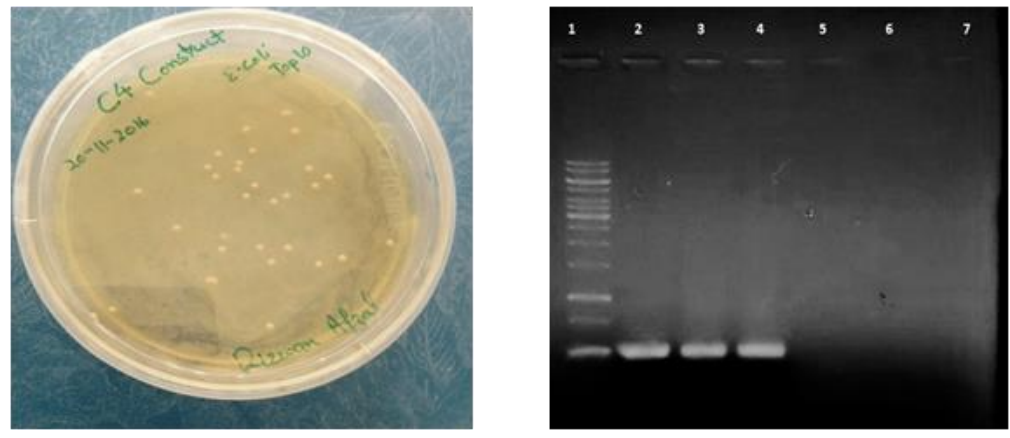

Fig. 2: C4 Plasmid amplification via Transformation

Left: Transformed bacterial colony of E. Coli Top10 strain with C4 construct plasmid Right: Confirmation of Plasmid C4 on Gel Lane 1: DNA ladder of 500 bp, Lane 2-4: Plasmid of construct C4
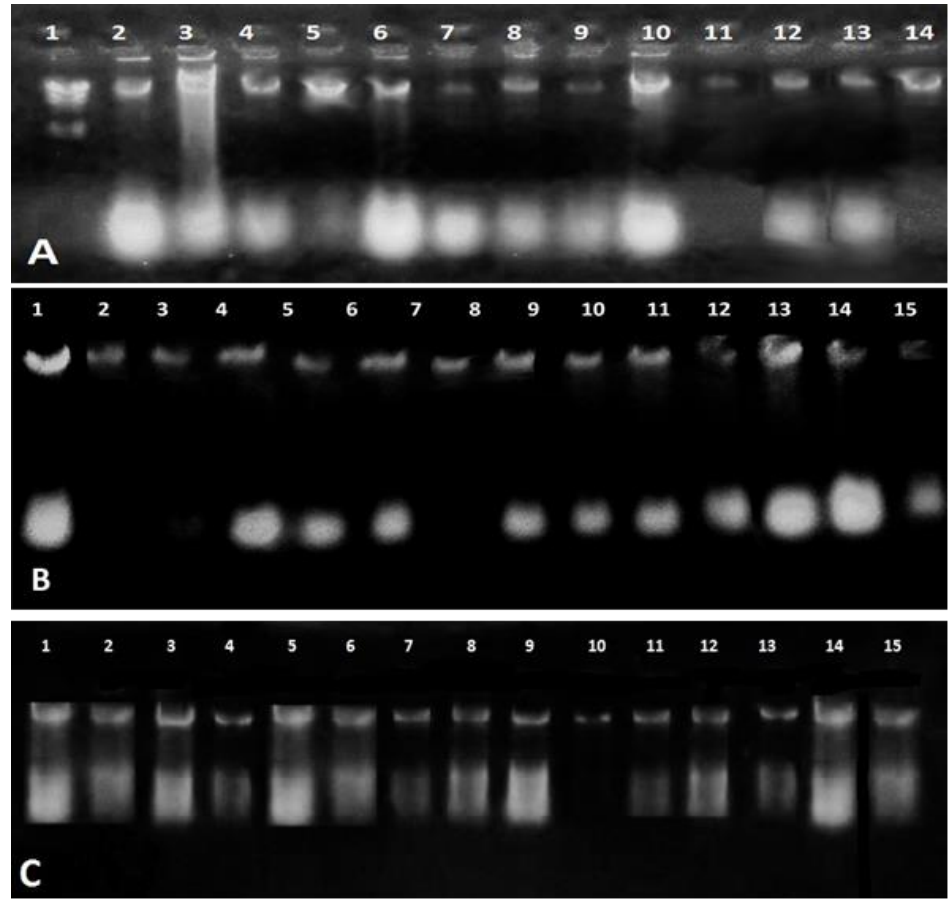

Fig. 3: Isolated DNA from Transgenic cotton MNH-786 Variety plants

A: Lane 1: Lambda Hind III, Lane 2-14: Total DNA of Transgenic Plants, B: Lane 1-15: Total DNA of Transgenic Plants, C: Lane 1-15: Total DNA of Transgenic Plants

of top right Fig. Lane 1 showed 50 bp Ladder, Lane 2 depicted amplified plasmid for positive control, Lanes 3-6 \& 8-12 explains positive transgenic plants, and Lane showed 7 non - transgenic plants (Fig. 4B). Moreover, Lane 1 showed the $100 \mathrm{bp}$ Ladder, Lane 2 depicted amplified plasmid for positive control, Lane 3 explainede the negative control, Lanes 4-5, 7-9 \& 11-15 showed the positive transgenic plants, and Lanes 7, 10 and 16 exhibited non transgenic plants (Fig. 4C). A look into the bottom left Fig. Lane 1 shows the 100 bp Ladder, Lane 2 explains the amplified plasmid for positive control, Lane 3 showed the negative control, Lanes 4-5, 7-8, 11-13 \& 15-16 showed positive transgenic plants, and Lanes $6,9,10 \& 14$ demonstrated non - transgenic plants (Fig. 4D).

Fig. 5 demonstrated the PCR to confirm the viral titer in transgenic plants, where Lane 1 showed 20 bp DNA Ladder, Lane 2 explained the positive viral DNA, Lanes 3 to 5 exhibited resistant group plants without virus load, Lanes 6 to 8 showed the tolerant group of plants without virus load, Lanes $9 \& 10$ demonstrated the susceptible group of plants with viral load and Lanes 11 to 15 expressed the negative control without DNA (Fig. 5).

Real time results for quantification of viral load in transgenic cotton plants of $\mathrm{C} 4$ construct graphically presented in expressed that WTC (Wild Type Control) showed presence of no virus titer load, NC (Negative Control) showed 4.5, RTCP (Resistant Transgenic cotton plant) negligible viral load, TTCP (Tolerant transgenic cotton plant) showed 0.5 and STCP (Susceptible transgenic cotton plant) showed 2.5 viral load (Fig. 6). 


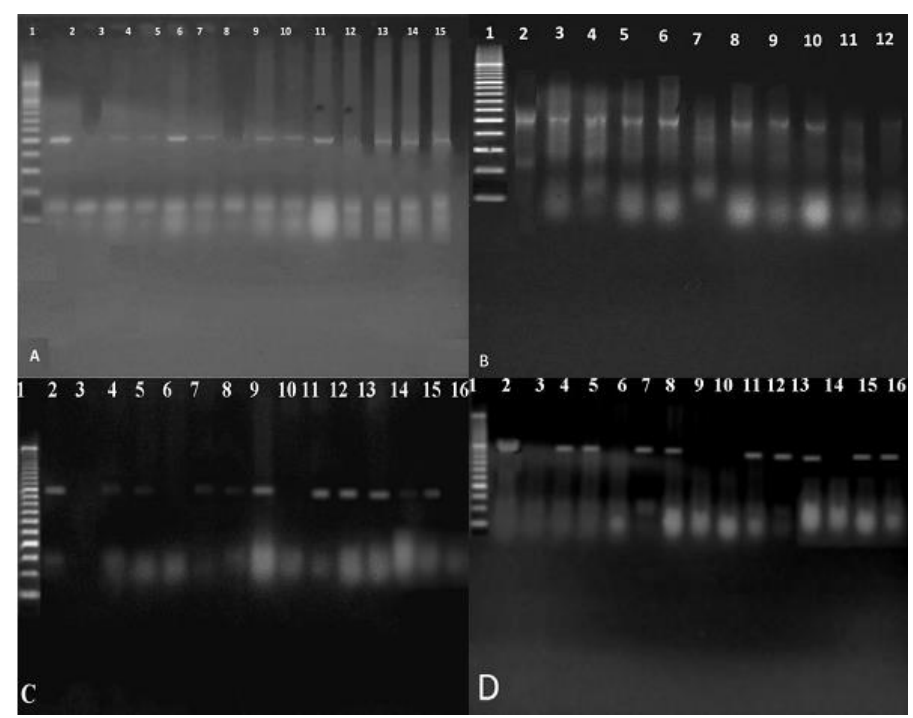

Fig. 4: PCR Amplification of Transgenic Cotton with gene specific primers for $\mathrm{C} 4$ gene Construct

A: Lane 1: 50 bp Ladder, Lane 2: Amplified plasmid for Positive Control, Lane 3: Negative Control, Lane 4-7,9-11 \& 13-15: Positive transgenic Plant, Lane 8 \& 12: NonTransgenic plants. B: Lane 1: 50 bp Ladder, Lane 2: Amplified plasmid for Positive Control, Lane 3-6 \& 8-12: Positive transgenic Plant, Lane 7: Non - Transgenic plants. C: Lane 1: 100 bp Ladder, Lane 2: Amplified plasmid for Positive Control, Lane 3: Negative Control, Lane 4-5, 7-9 \& 11-15: Positive transgenic Plant, Lane 7, 10 and 16: Non Transgenic plants D: Lane 1: 100 bp Ladder, Lane 2: Amplified plasmid for Positive Control, Lane 3: Negative Control, Lane 4-5,7-8,11-13 \&15-16: Positive transgenic Plant, Lane 6,9, 10 \& 14: Non-Transgenic plants

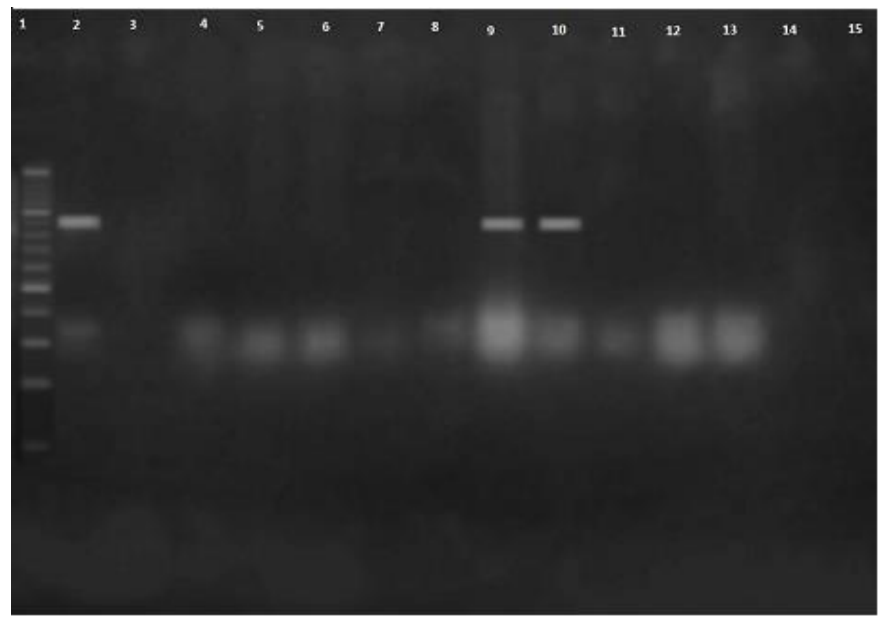

Fig. 5: PCR to confirm the viral titer in transgenic plants

Lane 1: 20bp DNA Ladder, Lane 2: positive Viral DNA, Lane 3 to 5: Resistant group plants without virus load, Lane 6 to 8: Tolerant group plant without virus load, Lane 9 \& 10: Susceptible group plants with viral load, Lane 11 to 15: Negative control without DNA

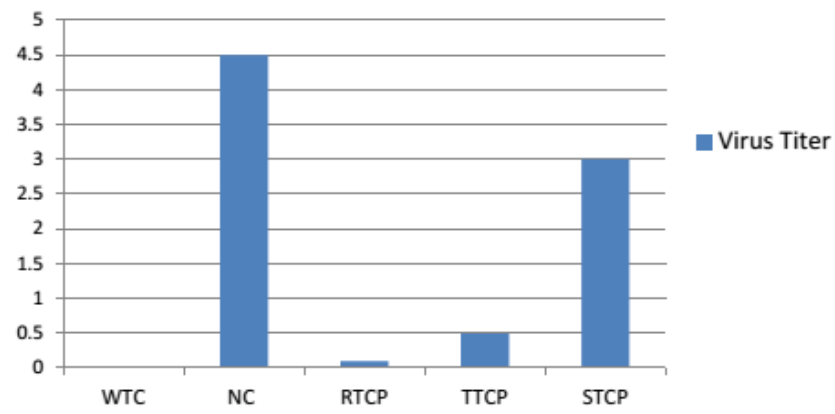

Fig. 6: Graph showing real time results for quantification of Viral load in transgenic cotton plants of C4 construct WTC: Wild Type Control, NC: Negative Control, RTCP: Resistant Transgenic cotton plant, TTCP: Tolerant transgenic cotton plant, STCP: Susceptible transgenic cotton plant 


\section{Discussion}

Now a days, pathogen derived resistance has been demonstrated to be efficient to control virus diseases in many virus-plant systems. The idea of pathogen derived resistance was given by two scientists, Sanford and Johnston in the mid of 80s. Since then, many strategies have been done to control viral infection in important field crops. Some exercises proved profitable and gave very good results in disease control. Based on pathogen derives resistance technique many safe varieties of papaya and squash were developed in the mid-1990s. Previous studies show that Pathogen derived resistance is a very useful tool in controlling viral diseases in mungbean plants (Carli et al. 2016). Mungbean yellow mosaic virus (MYMV) is a very devastating virus of mungbean crop in India. It has been causing severe losses for many years (Singh et al. 2013). Many methods have been developed to control this virus so far. Pathogen derived resistance proved one of the best methods to control this (Joshi et al. 2014; Verma et al. 2014). Development of resistant varieties has also been done by using pathogen derived resistance in mungbean plants.

In this study, work was done to check the ability of transgenic cotton MNH-786 variety with transformed construct of two virus resistance i.e., pathogen derived resistance against begomoviruses and Amplicon based RNAi construct targeting Beta-satellites. Variation in expression of these genes was studied by using various molecular techniques. All sown transgenic plants were screened based on molecular analysis. First to confirm the region of transformed $\mathrm{C} 4$ construct in the Plant genome, PCR was performed with specific primers with product size of 499 bp. From forty-five experimental transgenic cotton plants thirty-four were found positive putative transgenic plants. From these putative plants, plant was selected on the basis of morphological characteristic and categorized into resistant, tolerant and susceptible for whitefly assay. After feeding of whiteflies, virus titer was quantified by Real Time PCR. From the results of real time PCR, it became evident that resistant transgenic cotton plant has the least virus titer as compared to tolerant and susceptible transgenic cotton plant. Negative control cotton plant had maximum virus load of $\mathrm{CLCuV}$. Almost negligible virus titer was noted in resistant transgenic cotton plant. Susceptible transgenic cotton plant confirmed promising expression of construct $\mathrm{C} 4$ virus resistant genes. Same results were also described in VH-289 variety of cotton with V2 RNAi based construct where RT-PCR showed that transgenic lines had low virus titer compared to wild-type control plants upon challenging them with viruliferous whiteflies in contained environment.

Transgenic cotton plants with construct ihp RNAi construct upon inoculation also showed resistance with least virus titer (Khatoon et al. 2016). Plants become more resistant when they were inoculated with viral genes rather than coat protein genes (Retnosari et al. 2018). They showed resistance only against the viruses for they become transformed but also against several other viruses. Plants defense genes become more adaptive against several viruses when plants are transformed with viral DNA genes Keshavareddy et al. (2018). Our studies based on viral DNA genes inoculation. When begomovirus inoculated biologically with the help of whiteflies, plants showed significance resistance against this virus. From the Field, data was collected from putative positive transgenic plants of MNH-786 variety and were evaluated as Resistant, tolerant and susceptible at maturity with five replications. Other morphological parameters i.e., Monopodial branches per plant, Sympodial branches per plant, no of total leaves per plant, no of infected leaves per plant, no of bolls per plant, yield per plant and height of each plant were also observed. Monopodial branches per plant and total no of leaves have non-significant variance and are reduced due to $\mathrm{CLCuV}$ infection. Other parameters were all found significant result. Most significant traits were shown by no. of bolls and Total yield per plant with significant value > 0.001 . This result indicate that resistance group has more no of bolls and yield in compare to other groups. In previous research, reduction in no of bolls, no of total leaves and Yield was noticed (Raza et al. 2016).

\section{Conclusion}

CLCuV infection led to a significant change in all the parameters studied during the course of the research with the exception of number of monopodial branches per plant and total number of leaves per plant. Molecular analysis of transgenic plants showed that expression of construct 4 virus resistant gene against begomoviruses in resistant and tolerant group of transgenic plant was more comparative to susceptible and control. Susceptible group although found as positive putative plants with virus resistant. Being one of the most economical crops cotton is the need of future to draw genetic engineering strategies to overcome its major threat of Cotton Leaf Curl Disease that affects its yield.

\section{Acknowledgements}

The authors are thankful to University of the Punjab, Lahore for providing the resources for the current study

\section{Author Contributions}

MTM \& AAS planned the experiemnt, MRA performed the experiments SA AF \& SN statistically analyzed data \& interpretted the results MRT MMA analysed data reveiwed manuscript MA \& NR collected and alanlyzed data statistically analyzed the data and made illustrations

\section{Conflict of Interest}

Atuhors have no conflict of interest 


\section{Data Availability}

Corresponding authors have all the raw data with them that can be accessed

\section{Ethics Approval}

Authors declare that the research study has been carried out followiing all the scientific ethics

\section{Funding Source}

No specified funding for the current research study

\section{References}

An C, S Saha, JN Jenkins, BE Scheffler, TA Wilkins DM Stelly (2007) Transcriptome profiling, sequence characterization, and SNP-based chromosomal assignment of the EXPANSIN gene in cotton. $\mathrm{Mol}$ Genet Genom 278:539-553

Azhar MT, MU Rehman, S Aftab, Y Zafar, S Mansoor (2010). Utilization of natural and genetically-engineered sources in Gossypium hirsutum for the development of tolerance against cotton leaf curl disease and fiber characteristics. Intl J Agric Biol 12:744-748

Carli MD, PD Rossi, P Paganin, AD Fiore, F Lecce, C Capodicasa, L Bianco, G Perrotta, A Mengoni, G Bacci, L Daroda (2016). Bacterial community and proteome analysis of fresh-cut lettuce as affected by packaging. FEMS Microbiol Lett 363Article fnv209

Gallitelli D, GP Accotto (2001). Virus-resistant transgenic plants: Potential impact on the fitness of plant viruses. J Plant Pathol 83:3-9

Hernández-Centeno, FM Hernández-González, HY López-De la Peña, R López-Trujillo, PB Zamudio-Flores, E Ochoa-Reyes, JM TiradoGallegos, DG Martínez-Vázquez (2020). Changes in oxidative stability, composition and physical characteristics of oil from a nonconventional source before and after processing. Rev Mexic Ingen Quím 19:1389-1400

Hull R (2001). Matthews' Plant Virology, Vol. 1, pp:98-99. Academic Press San Diego, California, USA

Ilyas M, I Amin, S Mansoor, RW Briddon, M Saeed (2011). Challenges for transgenic resistance against geminiviruses. In: Emerging Geminiviral Diseases and their Management, pp:1-35. Sharma P, RK Gaur, M Ikegami (Eds). Nova Science Publishers, New York, USA

Johnson J (2000). A heuristic method for estimating the relative weight of predictor variables in multiple regression ession. Multivar Behav Res 35:1-19
Joshi, RS, VS Gupta, AP Giri (2014). Differential antibiosis against Helicoverpa armigera exerted by distinct inhibitory repeat domains of Capsicum апnuиm proteinase inhibitors. Phytochemistry 101:16-22

Keshavareddy G, ARV Kumar, VS Ramu (2018). Methods of plant transformation - A review. Int J Curr Microbiol Appl Sci 7:26562668

Khatoon S, A Kumar, NB Sarin, JA Khan (2016). RNAi-mediated resistance against Cotton leaf curl disease in elite Indian cotton (Gossypium hirsutum). Virus Genes 52:530-537

Liu Y, M Schiff, R Marathe, SP Dinesh-Kumar (2002). Tobacco Rarl, EDS1 and NPR1/NIM1 like genes are required for $N$-mediated resistance to tobacco mosaic virus. Plant J 30:415-429

Mansoor S, RW Briddon, Y Zafar, J Stanley (2001). Geminivirus disease complexes: An emerging threat. Trends Plant Sci 8:128-134

Mittler R, E Blumwald (2010) Genetic engineering for modern agriculture: Challenges and perspectives. Plant Cell 10:461-473

Oerke EC, HW Dehne (2004). Safeguarding production-losses in major crops and the role of crop protection. Crop Prot 23:275-285

Retnosari A, S Widyaningrum, WN Hidayati, WD Sawitri, N Darsono, T Hase, B Sugiharto (2018). Full sequence of the coat protein gene is required for the induction of pathogen-derived resistance against sugarcane mosaic virus in transgenic sugarcane. Mol Biol Rep 45:2749-2758

Raza S, FU Yousaf, Rajer (2016). Plant growth promoting activity of volatile organic compounds produced by bio-control strains. Sci Lett 4:40-43

Rojo-Gutiérrez E, JJ Buenrostro-Figueroa, R Natividad-Rangel, R RomeroRomero, DR Sepúlveda, R Baeza-Jiménez (2020). Effect of different extraction methods on cottonseed oil yield. Rev Mexic Ingen Quím $1: 385-394$

Rufell MR, C Hagen, WJ Lucas, RL Gilbertson (2002). Exploiting chinks in the plant's armor: Evolution and emergence of geminiviruses. Ann Rev Phytopathol 43:361-394

Saha T, A Kumar, M Ravindran, C Jacob, B Roy, M Nazeer (2002). Indentification of Colletotrchum acutatum from rubber using random amplified poly,orphic DNAs and ribosomal DNA polymorphism. Mycol Res 106:215-221

Singh AK, RC Bharati, A Pedpati (2013). An assessment of faba bean (Vicia faba L.) current status and future prospect. Afr J Agric Res 8:6634-6641

Ulloa L, D Messmer (2006). High-mobility group box 1 (HMGB1) protein: Friend and foe. Cytokin Growth Fact Rev 17:189-201

Verma MS, PZ Chen, L Jones, FX Gu (2014). "Chemical nose" for the visual identification of emerging ocular pathogens using gold nanostars. Biosens Bioelectr 61:386-390

Zhang XC, W Gassmann (2003). RPS4-mediated disease resistance requires the combined presence of RPS4 transcripts with full length and truncated open reading frames. Plant Cell 15:2333-2342 